\title{
Changes in Protein Fractions Level in Blood Plasma of Female Chinchillas during Pregnancy and Lactation.
}

\author{
Joanna GROMADZKA-OSTROWSKA \& Barbara ZALEWSKA
}

Gromadzka-Ostrowska J. \& Zalewska B., 1984: Changes in protein fractions level in blood plasma of female chinchillas during pregnancy and lactation. Acta theriol., 29, 19: 243-250 [With 4 Tables \& 3 Figs.]

Changes in plasma protein fractions level during pregnancy, lactation and in nonpregnant, nonlactating female chinchillas were investigated. Pregnancy and lactation were divided into following periods: from first to 37 th day, from 38 th to 74 th day, from 75 th to 111 th day (pregnancy) and from 7th to 20th day, from 30th to 46th day and from 54 th to 62nd day (lactation). During pregnancy $\alpha_{2}$-globulin level increase whereas $\beta_{2}$-globulin fraction level decrease, both significantly. Changes in other protein fractions level and in total protein plasma concentration during pregnancy were non significant. Pregnant females in comparison to nonpregnant ones have a significant higher level of $\alpha_{2}, \beta_{2}$, and $\gamma$-globulin levels whereas albumins and $\beta_{1}$-globulin levels were significantly lower. During lactation $\beta_{1}$-globulin level decrease from period I to II, whereas $\beta_{2}$-globulin level increase in the same time. In III lactation period $\beta_{2}$ and $\gamma$-globulin levels decreased. Lactating females in comparison to pregnant ones have a higher $\beta_{1}$-globulin level and lower $\beta_{2}$-globulin level. A small increase in total protein plasma concentration and albumins level and small decrease in $\gamma$-globulin level were also found in lactating females. Pregnant females comparatively to lactating (1.03) and nonpregnant, nonlactating ones (1.27) have lower $\mathrm{A} / \mathrm{G}$ ratio $(0.97)$

[Physiological Laboratory, Warsaw Zoological Garden, 03-461 Warszawa, Ratuszowa $1 / 3$, Poland]

\section{INTRODUCTION}

Chinchillas, rodents belonging to suborder Hystricomorpha, are a polyestric animals characterized by long gestation (105-111 days) with a low fertility (Asdell, 1964; Weir, 1966; Weir, 1967; Jarosz \& Rżewski, $1969)$ and long lactation (60 days) as was described by Jarosz \& Rżewski (1969).

Physiology of chinchilla pregnancy and lactation has received a very little attention (Jarosz \& Rżewski, 1969; Roberts, 1971). Protein metabolism during these physiological events in chinchillas have not been studied.

The present study was undertaken for comparing the plasma protein composition at different stages of pregnancy and lactation in chinchillas with this in nonpregnant, nonlactating ones.

\section{MATERIAL AND METHODS}

Investigations were carried out on 12 chinchilla females (Chinchilla laniger Molina, 1782) from laboratory breeding colony. Females and males were housed in pairs, cages were kept in room at temperature $4^{\circ} \mathrm{C}$ in winter and $25^{\circ} \mathrm{C}$ in summer 
and at humidity of $90 \%$ and $65 \%$ respectively. Feeding system was equal to this described by Jarosz \& Rżewski (1969) and consisted a stuff food, green forage or fruits and water ad lib.

Blood samples were obtained from the same females before mating (nonpregnant, nonlactating females), during pregnancy (pregnant females) and during lactation (lactating females). Blood was taken from the tail end into heparynized glass tubes according to Stoltz \& Bendall (1975) at particular days of pregnancy and lactation and $2-3$ times in 10 days intervals before mating.

Blood samples collected in particular pregnancy days were grouped in 3 pregnancy periods: samples from first to 37th day, from 38th to 74th and from 75th to 111th pregnancy day. From lactating females blood samples were collected in particular days of lactation and grouped also in 3 periods: from 7th to 20th, from 30 th to 46 th and from 54 th to 62 th lactation day. In early lactation (1-6 day) blood samples were not obtained. Plasma was separed by centrifugation and stored at $-20^{\circ} \mathrm{C}$ until assayed.

Plasma proteins were separed by paper electrophoresis method (Dżulyńska et al., 1964). Electrophoretic analysis have been performed with veronal buffer, $\mathrm{pH}=9.0,0.1$ ionic strenght at $160 \mathrm{~V}$ tension during 18 hours. The strips were stained with $5 \%$ Amido Black 10B. Percentage of the protein fractions were calculated from the electrophoretic patterns obtained densytometrically (Ostrowski, 1970).

Total plasma protein concentration was determined by the mehod of Lowry et al. (1951). Because a small amount of blood was yielded from chinchillas total plasma protein determinations only in a part of samples were made. All protein plasma fractions data were presented as relative values $(\%)$.

The data were analysed according to the Student's $t$ test at $p \leqslant 0.05$ and $p \leqslant 0.01$ as differences statistically significant.

\section{RESULTS}

Plasma proteins of the chinchilla were separed into six bands. The integrating scaner recorded six peaks that were identified as albumin, $\alpha_{1}, \alpha_{2}, \beta_{1}, \beta_{2}$ and $\gamma$-globulins. All six fractions were present in the plasma of each chinchilla.

Electrophoretic diagrams of blood plasma protein fractions in nonpregnant and pregnant female are presented on Fig. 1. Arrows on pregnant female diagram indicate direction in changes of protein fractions level during pregnancy.

Percent concentrations of plasma protein fractions during particular stages of pregnancy are presented in the Table 1 and on the Fig. 2. During pregnancy $\alpha_{2}$-globulin fraction level increase significantly from $5.94 \pm 0.47 \%$ in period I to $7.48 \pm 1.16 \%$ in period II and $8.64 \pm$ $\pm 0.91 \%$ in period III $(p \leqslant 0.05)$. $\beta_{2}$-globulin fraction level decrease from $11.5 \pm 1.73 \%$ in period $I$ to $9.40 \pm 0.78 \%$ in period II and stay at the same level till parturition. Changes in other protein fractions were non significant. Total plasma protein concentration not changes significantly during pregnancy and varied between $5.77 \pm 0.64 \mathrm{~g} \%$ and $6.83 \pm 0.38 \mathrm{~g} \%$ with mean value of $6.21 \pm 0.34 \mathrm{~g} \%$ (Table 4). Albumin/globulin ratio increase as pregnancy progressed in period I and II and decrease in period III (Fig. 3, Table 1). 


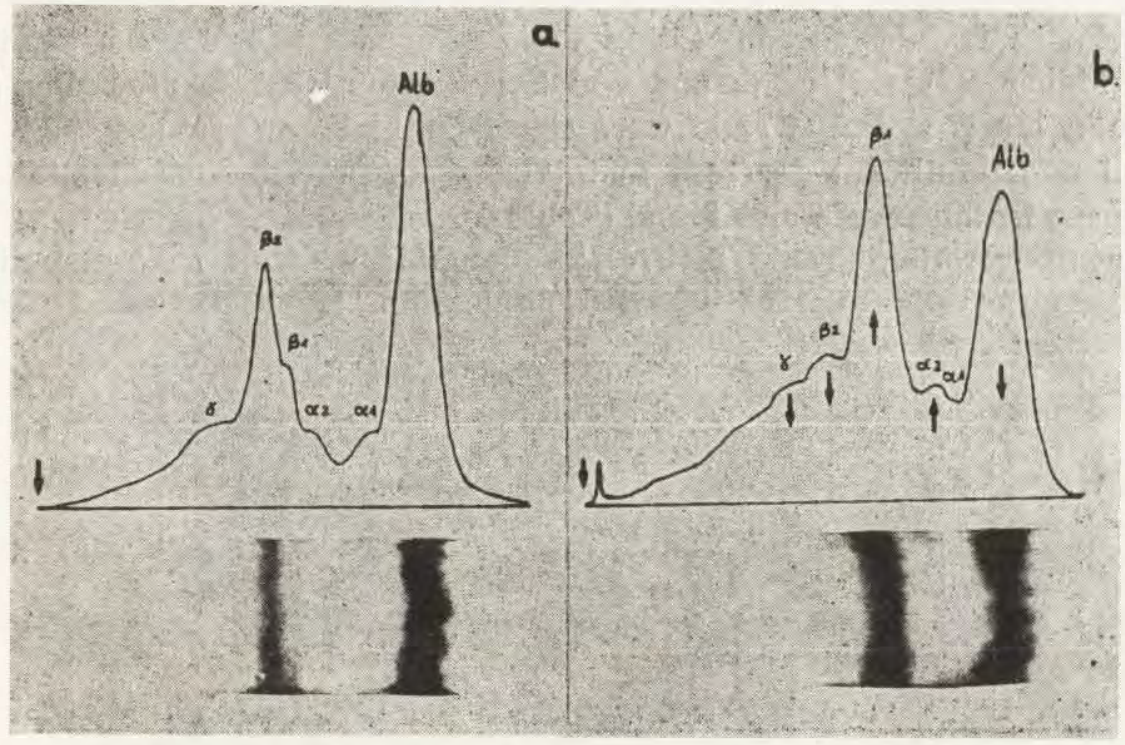

Fig. 1. Electrophoretic diagrams of chinchilla females plasma protein fractions: a) nonpregnant female, b) pregnant female.

Arrows on the diagram indicate direction in protein fractions changes.

\section{Table 1}

Plasma protein fractions level $(\%)$ changes during chinchilla pregnancy $(\bar{x} \pm \mathrm{SE})$.

${ }_{1}^{1}$ Figure indicate significant differences at $p \leqslant 0.05$. Numbers in paranthesis indicate sample size.

\begin{tabular}{lrrrrrrr}
\hline $\begin{array}{l}\text { Pregnancy } \\
\text { days }(\mathrm{n})\end{array}$ & $\begin{array}{c}\text { Albu- } \\
\text { mins }\end{array}$ & $\begin{array}{c}\alpha_{1}- \\
\text { glob. }\end{array}$ & $\begin{array}{c}\alpha_{2}- \\
\text { glob. }\end{array}$ & $\begin{array}{c}\beta_{1}- \\
\text { glob. }\end{array}$ & $\begin{array}{c}\beta_{2-} \\
\text { glob. }\end{array}$ & $\begin{array}{c}\gamma- \\
\text { glob. }\end{array}$ & $\begin{array}{c}\text { A/G } \\
\text { ratio }\end{array}$ \\
\hline $1-37(18)$ & 48.7 & 6.03 & 5.94 & 11.6 & 11.5 & 15.9 & 0.93 \\
& \pm 1.50 & \pm 0.44 & \pm 0.471 & \pm 1.48 & $\pm 1.73^{1}$ & \pm 1.88 & \\
$38-74(26)$ & 50.8 & 5.86 & 7.48 & 12.9 & 9.4 & 13.5 & 1.03 \\
& \pm 1.76 & \pm 0.49 & \pm 1.16 & \pm 0.84 & $\pm 0.78^{1}$ & \pm 1.16 & 0.90 \\
$75-111(22)$ & 47.4 & 6.09 & 8.64 & 13.4 & 9.7 & 14.6 & 0.90 \\
& \pm 1.56 & \pm 0.53 & $\pm 0.91^{1}$ & \pm 1.19 & \pm 0.86 & \pm 1.20 & \\
\hline
\end{tabular}

\section{Table 2}

Plasma protein fractions level $(\%)$ changes during chinchilla lactation $(\bar{x} \pm \mathrm{SE})$. 1 Figure indicate significant differences at $p \leqslant 0.05$. Numbers in paranthesis indicate in paranthesis indicate sample size.

\begin{tabular}{cccccccc}
\hline $\begin{array}{c}\text { Pregnancy } \\
\text { days }(\mathrm{n})\end{array}$ & $\begin{array}{c}\text { Albu- } \\
\text { mins }\end{array}$ & $\begin{array}{c}\alpha_{1}- \\
\text { glob. }\end{array}$ & $\begin{array}{c}\alpha_{2}- \\
\text { glob. }\end{array}$ & $\begin{array}{c}\beta_{1-} \\
\text { glob. }\end{array}$ & $\begin{array}{c}\beta_{2^{-}} \\
\text {glob. }\end{array}$ & $\begin{array}{c}\gamma- \\
\text { glob. }\end{array}$ & $\begin{array}{c}\text { A/G } \\
\text { ratio }\end{array}$ \\
\hline $7-20(6)$ & 50.3 & 58 & 7.2 & 14.8 & 7.3 & 14.5 & 1.01 \\
& \pm 2.76 & \pm 0.98 & \pm 1.14 & $\pm 1.08^{2}$ & $\pm 1.23^{1}$ & \pm 2.43 & \\
$30-46(5)$ & 48.4 & 7.0 & 6.6 & 8.8 & 13.2 & 16.4 & 0.93 \\
& \pm 3.44 & \pm 0.89 & \pm 1.12 & $\pm 1.45^{2}$ & $\pm 1.82^{1}$ & \pm 4.49 & 1.12 \\
$54-65(5)$ & 53.0 & 7.0 & 11.0 & 10.8 & 8.8 & 9.6 & 1.12 \\
& \pm 2.21 & \pm 0.83 & \pm 3.11 & $\pm 1.39^{1}$ & \pm 1.93 & \pm 1.60 & \\
\hline
\end{tabular}


Pregnant females in comparison to nonpregnant ones have a significant higher levels of $\alpha_{2}, \beta_{2}$ and $\gamma$-globulin levels whereas albumins, $\beta_{1-}$ globulin levels and A/G ratio were significantly lower (Table 3, Fig. 3). Small non significant decrease in total plasma protein concentration in pregnant females were also found (Table 4).

During lactation (Table 2. Fig. 2) albumins as well as $\alpha$-globulins fractions not change significantly. $\beta_{1}$-globulin level decreased from

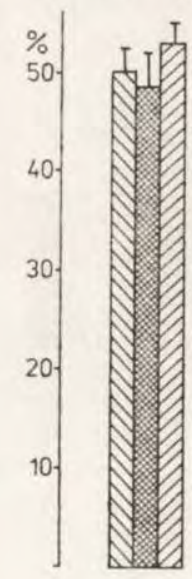

Lactation

$$
\begin{aligned}
& \triangle \text { from } 7 \text { to } 20 \text { days } \\
& \text { from } 30 \text { to } 46 \text { days } \\
& \text { from } 54 \text { to } 62 \text { days }
\end{aligned}
$$
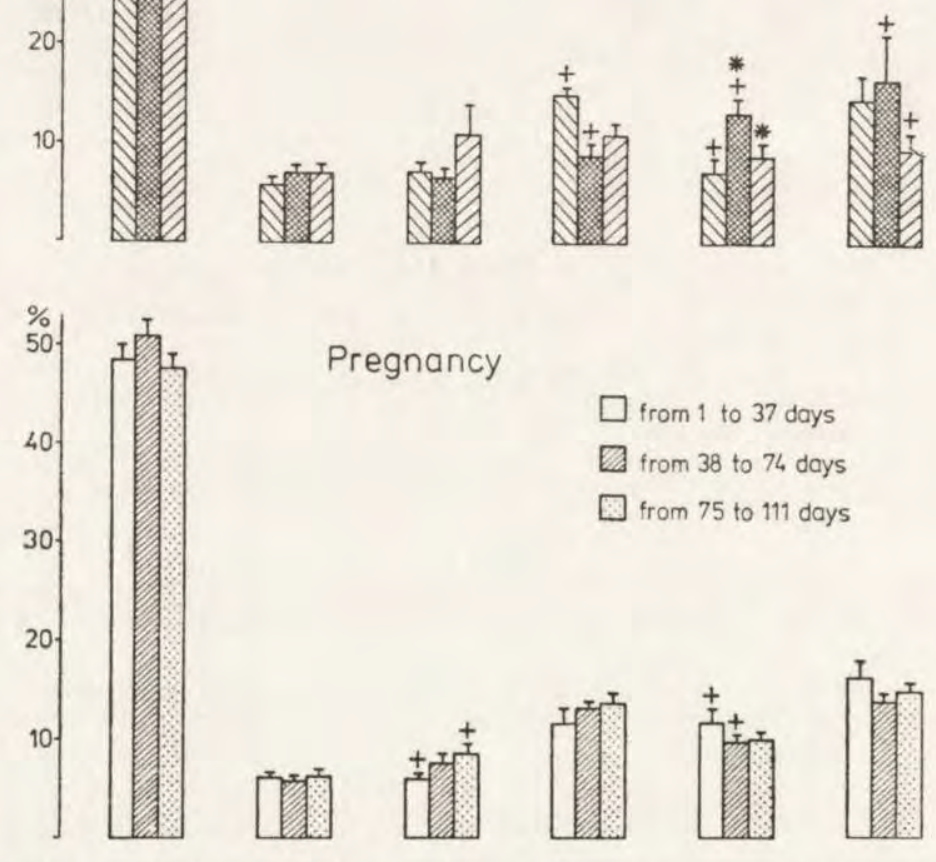

$$
\begin{aligned}
& \square \text { from } 1 \text { to } 37 \text { days } \\
& \square \text { from } 38 \text { to } 74 \text { days } \\
& \square \text { from } 75 \text { to } 111 \text { days }
\end{aligned}
$$

Fig. 2. Changes in plasma protein fractions $(\%)$ during pregnancy and lactation of chinchillas.

Vertical bar indicate 1 standard error, symbols above columns indicate significant differences between lactation and pregnancy periods at $\mathrm{P}=0.05(+)$ and $\mathrm{P}=0.01\left(^{*}\right)$.

$14.8 \pm 1.08 \%$ in period I to $8.8 \pm 1.45 \%$ in period II $(p \leqslant 0.01)$ and then a little increased to $10.8 \pm 1.39 \%$ in period III. $\beta_{2}$-globulin level increased significantly $(p \leqslant 0.05)$ from period I to II $(7.3 \pm 1.23 \%$ to $13.2 \pm$ $1.82 \%$ ) and decrease to $8.8 \pm 1.93 \%$ in period III. $\gamma$-globulin levels decreased from period II to period III $(16.4 \pm 4.49 \%$ to $9.6 \pm 1.60 \%)$. A/G ratio increase during period I of lactation in comparing with the last pre- 


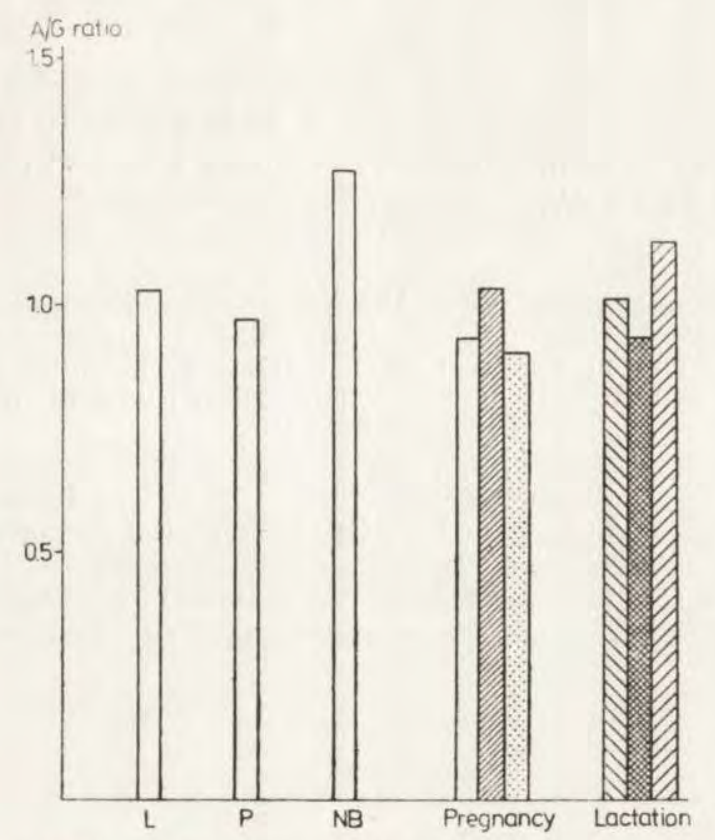

Fig. 3. Albumin-globulin ratio changes during particular periods of pregnancy and lactation and in pregnant (P), lactating (L) and nonpregnant nonlactating (NP) chinchillas.

\section{Table 3}

Plasma protein fractions concentration $(\%)$ in pregnant, lactating and nonpregnant nonlactating chinchilla females $(\bar{x} \pm \mathrm{SE})$.

1 Figures indicate significant differences at $p \leqslant 0.05 ; 2$ at $p \leqslant 0.01$. Numbers in paranthesis indicate sample size.

\begin{tabular}{lccr}
\hline $\begin{array}{c}\text { Protein } \\
\text { fractions }\end{array}$ & $\begin{array}{c}\text { Pregnant } \\
\text { females } \\
(66)\end{array}$ & $\begin{array}{c}\text { Lactating } \\
\text { females } \\
(16)\end{array}$ & $\begin{array}{c}\text { Nonpregnant } \\
\text { nonlactating } \\
\text { females } \\
(32)\end{array}$ \\
\hline Albumins & $48.9 \pm 2.42$ & $50.6 \pm 1.60$ & $\begin{array}{c}\text { (32) } \\
\alpha_{1} \text {-glob. }\end{array}$ \\
$\alpha_{2}$-glob. & $6.1 \pm 0.72$ & $6.6 \pm 0.46$ & $7.5 \pm 1.40$ \\
$\beta_{1}$-glob. & $7.9 \pm 1.39^{1}$ & $8.2 \pm 1.15$ & $4.4 \pm 0.46^{1}$ \\
$\beta_{2}$-glob. & $10.3 \pm 0.88^{2}$ & $11.1 \pm 1.171$ & $15.6 \pm 2.36^{2}$ \\
$\gamma$-glob. & $12.3 \pm 1.25^{2}$ & $9.6 \pm 1.091$ & $6.4 \pm 1.40^{2}$ \\
A/G ratio & $14.5 \pm 1.28^{1}$ & $13.6 \pm 1.78$ & $10.1 \pm 2.05^{1}$ \\
\hline
\end{tabular}

gnancy period $(0.90)$, decrease in II lactation period (0.93) and during III period increase again (1.12) towards the level found in nonpregnant nonlactating females (Table 2, Fig. 3 ).

Lactating, nonpregnant females in comparison to pregnant ones (Table 3 ) have a higher $\beta_{1}$-globulin level $(11.1 \pm 1.17 \%$ and $10.3 \pm 0.88 \%)$ respectivelly), and lower $\beta_{2}$-globulin level $(9.6 \pm 1.09 \%$ and $12.3 \pm 1.25 \%$ respectively). A small rise in $\alpha_{2}$-globulin level and small non significant 
decrease in $\gamma$-globulin level in lactating females were also observed. Total plasma protein concentration (Table 4) as well as albumins level (Table 3) and A/G ratio (Fig. 3) were a little higher in lactating females in comparison to pregnant ones $(7.04 \pm 0.56 \mathrm{~g} \%, 6.21 \pm 0.34 \mathrm{~g} \%$ and $50.6 \pm 3.02 \%, 48.9 \pm 2.42 \%$ ).

\section{Table 4}

Total protein concentrations $(\mathrm{g} \%)$ in blood plasma during different pregnancy stages, lactation and in nonpregnant nonlactating chinchilla females ( $\bar{x} \pm \mathrm{SE})$.

Control group - nonpregnant nonlactating females, Numbers in paranthesis indicate sample size.

\begin{tabular}{|c|c|c|c|c|c|}
\hline \multicolumn{4}{|c|}{ Pregnancy } & \multirow{2}{*}{$\begin{array}{l}\text { Lactation } \\
\text { (6) }\end{array}$} & \multirow{2}{*}{$\begin{array}{c}\text { Control } \\
\text { group (14) }\end{array}$} \\
\hline Period I (4) & Period II (6) & Period III (4) & Average (14) & & \\
\hline $6.83 \pm 0.38$ & $5.77 \pm 0.64$ & $6.24 \pm 0.82$ & $6.2 \mathrm{i} \pm 0.34$ & $7.04 \pm 0.56$ & $6.82 \pm 0.30$ \\
\hline
\end{tabular}

\section{DISCUSSION}

The chinchilla is characterized by long gestation and long lactation. The range of gestation is $105-113$ days, in most animals the period is 111 days (Asdell, 1964; Weir, 1966; Jarosz \& Rżewski, 1969; Roberts, 1971). Lactation is about 60 days (Jarosz \& Rżewski, 1969). The long pregnancies of these rodents are due to the extremally slow rate of foetus growth particulary in the early stages of pregnancy (Roberts, 1971).

Plasma proteins of the investigated chinchillas were separated into six fractions. This is a closely agreement with results obtained by others: Stauber et al. (1954), Eagle \& Woods (1960), Jones \& Bunde (1970). The changes in the plasma protein fractions level during pregnancy in chinchillas are generally the same as those occuring during pregnancy in other rodents: rabbits (Prusiewicz-Witaszek \& Działoszyński, 1967) and voles (Dobrowolska, 1975; Dobrowolska, 1982). Characteristic for all these rodent species is a small decrease in total plasma protein concentrations as well as albumins level diminution and increase in $\alpha_{2}$-globulin level which was due to increase in hormonal secretion, especially in gonadotrophins secretion (Bogdanikowa \& Murawski, 1968). This increasing trend in $\alpha_{2}$-globulin concentration may represents also a high tournover of minerals, especially iron and copper, during pregnancy (Kitts et al., 1971).

Lactation in chinchillas was accompanied by changes in the plasma $\beta$ and $\gamma$ globulin fractions but there were no significant changes in the concentrations of albumins and $\gamma$ globulins. These protein pattern changes are a little different than those found in rabbit lactation (Jordan \& Morgan, 1970). They showed that total protein concentration, albumins and $\gamma$ globulin concentrations in rabbit plasma increased significantlly 
as lactation progressed whereas $\alpha$ and $\beta$ globulins fractions not changed.

Significant decrease in $\beta_{2}$-globulin levels during pregnancy as well as increase in $\beta$-globulin levels found during early lactation in chinchillas may be due to the changes in antibody concentrations and may manifest that $\beta_{2}$-globulin fractions in chinchillas are a major immunoglobulins fraction.

\section{REFERENCES}

1. Asdell S. A. (ed.), 1964: Patterns of mammalian reproduction. Cornell University Press: $1-640$. London.

2. Bogdanikowa B. \& Murawski R., 1968: Rozpoznanie zmian w biakkach krwi. Państw. Zakł. Wyd. Lek.: 1-304. Warszawa.

3. Dobrowolska A., 1975: Electrophoretic pattern of proteins and glikoproteins in the blood serum of common voles in relation to the season and physiological activity. Acta theriol., 20: 435-441.

4. Dobrowolska A., 1982: Serum $\gamma$-globulin concentration in different stages of sexual activity in females of common vole (Microtus arvalis). Comp. Bioch. Physiol., 71: 465-467.

5. Dżułyńska J., Krajewska K. \& Gill J., 1964: Serum glikoproteins in some species of non-demonsticated mammals. Acta bioch. pol., 11: 121-128.

6. Eagle R. L. \& Woods K. R., 1960: The plasma proteins. Ed. F. W. Putnam. Academic Press: 200-20-. New York and London.

7. Jarosz S. \& Rżewski W., 1969: Chów szynszyli. Państw. Wyd. Roln. i Leśne: $1-131$. Warszawa.

8. Jones R. D. \& Bunde D. E., 1970: Age and sex differences in the serum proteins of the chinchilla. J. Mammal., 51: 425-429.

9. Jordan S. M. \& Morgan E. H., 1970: Plasma protein metabolism during lactation in the rabbit. Am. J. Physiol., 219: 1549-1554.

10. Kitts W. D., Krishnamurti C. R. \& Hudson R. J., 1971: Cellular blood constituents and serum protein fractions of the chinchilla (Chinchilla laniger). Can. J. Zool., 49: 1079-1084.

11. Lowry O. H., Rosenbrought N. J., Farr A. L. \& Randall P. O., 1951: Protein measurement with the Folin phenol reagent. J. Biol. Chem., 193: 265-275.

12. Ostrowski W., 1970: Elektroforeza w badaniach biochemicznych i klinicznych. Państw. Wyd. Nauk. 1-273. Warszawa.

13. Prusiewicz-Witaszek U. \& Działoszyński L., 1967: Wpływ ciąży i laktacji na poziom białek, gliko i lipoproteidów w surowicy krwi królików. Med. wet., 10: $627-630$.

14. Roberts C. M., 1971: The early development of some hystricomorph rodents with particular references to Chinchilla laniger. J. Reprod. Fert., 27: 488-489.

15. Stauber L. A., Ochs J. Q. \& Coy N. H., 1954: Electrophoretic patterns of the serum proteins of chinchillas and hamsters infected with Leishmania donovani. Exp. Parasitol., 3: 325-335.

16. Stoltz D. R. \& Bendall R. D., 1975: A simple technique for repeated collection of blood samples from mice. Lab. Anim. Sci., 25: 353-354.

17. Weir B. J., 1966: Aspects of reproduction in Chinchilla. J. Reprod. Fert., 12: 405-411.

18. Weir B. J., 1967: Aspects of reproduction in some hystricomorph rodents. Ph. D. thesis, University of Cambridge.

Accepted, April 24, 1984. 


\section{ZMIANY W POZIOMIE FRAKCJI BIAŁKOWYCH OSOCZA KRWI SZYNSZYLA} MAEEGO W CZASIE CIAZZZY I LAKTACJI

Badano zmiany stężenia frakcji białkowych i białka całkowitego osocza krwi zachodzące w czasie ciąży i laktacji szynszyla małego (Chinchilla lanigen Molina, 1782). Bialko oznaczano metodą Lowry'ego, frakcje białkowe - metodą elektroforezy bibułowej. Okres ciąży podzielono na trzy 73-dniowe podokresy. W czasie ciąży wzrasta istotnie poziom frakcji $\alpha_{2}$-globulinowej i obniża się poziom frakcji $\beta_{2}$-globulinowej (Tabela 1, Ryc. 2). Zmiany poziomu pozostałych frakcji białkowych oraz stężenia białka całkowitego (Tabela 4) nie są istotne. Samice ciężarne w stosunku do samic nieciężarnych mają niższy poziom frakcji albumin i $\beta_{1}$-globulin. Niższy jest też stosunek A/G (Tabela 3, Ryc. 3), natomiast wyższe są stężenia frakcji $\alpha_{2}-, \quad \beta_{2^{-}}$i $\gamma$-globulin (Tabela 3). Okres laktacji podzielono także na 3 podokresy: od 7 do 20 dnia, od 30 do 46 dnia i od 54 do 62 dnia. W czasie laktacji wzrasta poziom frakcji $\beta_{1}$-globulin a obniża się poziom $\beta_{2}$-globulin ( $\mathrm{Ta}$ bela 2, Ryc. 2). Zmiany stężenia innych frakcji nie są istotne. W stosunku do samic ciężarnych samice karmiące mają wyższy poziom $\beta_{1}$-globulin, a niższy $\beta_{\mathbf{2}}$-globulin (Tabela 3). Nieco wyższe jest teź stężenie albumin (Tabela 3 ) i białka . całkowitego (Tabela 4) oraz wyższy stosunek A/G (Tabela 3, Ryc. 3). 